\title{
Factors of Violence against Children, and Legislation to Protect Children from Violence in Albania
}

\author{
Neshet Ngucaj \\ Member of Vlora Chamber Advocacy \\ Myzafer Elezi \\ Lecturer Ismail Qemali Vlora University \\ myzafer.elezi@gmail.com
}

Doi:10.5901/mjss.2014.v5n6p389

\begin{abstract}
Maltreatment of children is today one of the most acute pressing problems that Albanian society is facing. Increasingly present is becoming a bitter reality of child abuse in various forms within and outside the family. Vulnerable children, orphans and children with divorced parents often fall "prey" of exploitation and rape in the most diverse forms. Legislation in force that affects children's issues in recent years has significantly enriched in accordance with internationally recognized standards. the goal of the paper is to made a analyze of leghal framework about the children protection from violence. for the realization of the papers goal, are uised method of literature review and analyse method, based in legal disposites of Albania The article analyse the defionition of the Costitution, the Civil Code, the Family Code, and Penal Code. After the evaluation it shows the differences in leghal codes, and identiofy some weakness point. Although progress has been made visible, completion of legislation on violence against children in Albania is not yet a systematic activity, but an activity that is designated with campaigns, which are defined more by the interest of international institutions, covering rights children.
\end{abstract}

Keyword: children protection, maltreatment of children, legal framework for children protection.

\section{Intoduction}

Although recent years are ratified a number of conventions, and other international laws related to violence against children, the Albanian legislation does not address the comprehensive and detailed manner, all aspects of violence against children. For example, if sexual violence and trafficking of children is a package of laws and specific provisions relatively physical violence and especially, emotional violence, neglect and financial exploitation of a child, laws and regulations are not comprehensive, undetailed and unaddressed specifically for children. In general, the Albanian legislation provides detail for penalties of violence perpetrators, when it has sexual nature or where it comes from trafficking. However, no provisions provided for child care and compensation for victims of violence. Violence towards children let different consequences to those which can be categorized into three groups:

- Consequences associated with mental health: depression, fear, anxiety, lack of self-esteem, anorexia and sleeplessness, traumatic disorders, attempted suicide.

- Consequences associated with physical health: death, disability or partial permanent injuries, drug and alcohol abuse, irritable bowel syndrome, destructive smoking, or unsafe sex.

- Consequences associated with reproductive health: unwanted pregnancies, gynecological problems, sexually transmitted diseases, abortion, underweight births, etc..

\section{Factors of Domestic Violence against Chlidren}

Surveys, studies, questionnaires have shown that factors that promote violence, are multi-layer. They can be categorized into:

- Macro-level factors, including: the impact of culture, economics, politics, etc. The large demographic movements. 
- Family-level factors, or micro, which may include: family relationships, models that are grown, family education, mothods which are grown up children, etc..

- Personal-level factors, which may include: mental health problems of the individual, abuse of alcohol, drugs, stress, education, various personality disorders, personal experiences in family relationships, etc..

\subsection{The neglect}

In Article 2 of the Family Code, emphasized parental responsibility for ensuring the welfare emotional, social and material child.

Article 69 and 71 of the Family Code provides that parents can not leave the child labors to raise and educate a person can not be trustee. Family Code determines the obligation and the right of parents to care for child food, and his education. Parents have the duty to provide moral and material welfare of the child, being cared for by providing education, growth, legal representation and administration of its goods. Parental responsibility for education and child development is realized through parental right that is the same for both parents.

Article 63 of the Family Code provides that parents have the same rights and duties towards their children.

Article 64 of the Family Code provides that the parental right is exercised only in the interest of the child.

So the exercise of parental responsibility is based on the stated interest of the child. Parental responsibility to children born out of wedlock is similar to that of the children born within marriage. In case of dissolution of marriage, Family Code provides that in determining child custody, the court is obliged to keep the primary priority, the interests of the child. Thus, the court takes into account the child's relationship with parents, the way of the realization of material needs, and the child's residence.

Article 125 of the Criminal Code provides that "Denial of living necessary for the children of the person pursuant to a court is obliged to grant constitutes a criminal offense and is punishable by fine or imprisonment up to one year."

But in the period 1990-1991, when Albania opened up to the world, and in the years to implement, many parents emigrated vendit. In many cases migration was accompanied by decay of families, numerous divorces, and many children remain without adequate aid for living and educated in normal conditions. Also, migration, and as a result has led to non-execution of court decisions, which determine food obligation of the parent that have fled the country. In order to enable the execution of these court decisions, Albania, is working to reach agreements with neighboring countries, where they work a good part of Albanian emigrants.

Article 70 of the Family Code, provides for the case where parents can ask the court, submitting their child when he does not live near them, and unjustly held by other persons.

The Criminal Code Article 127 provides that: "Taking the child unfairly, taking away from the person exercising parental authority entrusted for growth and education and retention of child parent, in the court order constitutes a criminal offense, and is punishable with a fine or imprisonment up to six months. "

Also in Family Code Article 215, provided extreme measures associated with the misuse of parental responsibility.

The law provides an extreme measure: removal of parental rights when a parent abuses parental responsibility when shows negligent in its exercise or when its parent's actions adversely affect the child's education.

Family Code provides for the cases when minors unable to stay with their parents and placed in foster care enjoy special protection from the state. These cases are mistreatment of children by parents, their lack of care, etc. removal of parental authority.

\subsection{The abandonment}

The abandonment of the child is provided as a criminal offense in the Criminal Code. So in the article 124: "Abandonment of minor children" provided as "Abandonment of children under age 14 years old by parent or person having custody child, is punishable with a fine or imprisonment up to three years." When abandonment has resulted in serious health damage or death, the sanction is imprisonment from three to ten years. The Albanian Constitution provides special protection for children from the state, being expressed in the comprehensive manier.

Family Code, in Article 10, provided the state's obligation for the the growth and education of children left without parents and without support ${ }^{1}$.

Article 59 of the Constitution of the Republic of Albania guarantees state care and help for orphans².

\footnotetext{
1 The Family Code of Republice of Albania, Article 10

2 Constitution of the Republic of Albaniam, Article 59
} 
Article 102 and 103 of the Family Code provides that when children are not under the care of parents when both parents have died or have been declared missing.Placed in foster care each should ensure that they have suitable conditions for the growth and development of versatile educating them ${ }^{3}$.Orphans placed at special institutions for children such as the child's home, health institutions etc. Orphans are persons who:

- born out of wedlock

- children who have no one of parents live

- children that the final decision of the court was stripped of parental rights

- was abandoned by both parents and not their identity is.

These children are in state custody, growth and educational development of their education is the duty of the state and enjoys the special protection of the state. Abandoned children placed at various institutions of child care.

Under the Code of Civil Procedure Article 351 requirements for establishing guardianship court submitted by relatives of the minor child, and anyone who receives a notice for the rest of the child without parents, for the birth of a child of unknown parents, and for every circumstance another that the law requires for placement of foster care ${ }^{4}$.

Care institutions for children living children until age 14. Children who have reached 14 years old, so you have finished 9-year-old school, attend schools with scholarship, and live in dormitories in the schools. After finishing high school, these young orphan and abandoned are under the protection of orphan status. According to this law, those benefiting economic, housing the work of municipalities. Orphan status provides free medical and dental services children. Occupations of these children are given priority by labor offices.

Another way to provide care for orphaned children in their growth and development as well as educational and social standards to ensure the best life is adoption.Adoption is regulated by both the Family Code and the Law "On adoption of minors". This law has been drafted in compliance with the UN Convention on the rights of children and the Hague Convention on international adoption. According to Article 1 of this law "adoption is permitted only in cases where the interests of the minor high and guarantees the respect of his rights." The National Committee for Adoption Is created, as competent body which prepares the necessary documentation for the adoption of the child at home and abroad, prior to the court. This Committee during its activity must fulfill the obligations arising from international conventions and agreements related to the protection of children's rights, ratified by Albania..

By law the acceptance, requests for making or receiving money and other material goods from a parent, guardian, or any other A person in the process of adoption of a juvenile sentenced to five years in prison. This provision is designed to prevent the abuses that have been with rats of minors by foreign citizens.

\subsection{Discrimmination}

Children separate layers, in practice, have some limitations that are characteristic for all the countries of South Eastern Europe and beyond. These restrictions do not have their source in discrimination by the state and its institutions, but relate more to the mentality of these layers.

Roma children generally live in poverty and difficult social conditions. Most of them live on the streets begging while in the summer season some of them, especially those living in cities and areas near the border, go to Greece for working. In these conditions, some of them fall victim to prostitution, physical and moral abused, mistreated and exploited by networks of illegal activities. Generally Roma children do not attend school regularly, do not apply the compulsory education and therefore characterized by a high level of illiteracy..

During the communist regime, children discriminated against, because of beliefs, or opinions expressed by their parents or other relatives of the family. Forms of discrimination were very varied, ranging from internment to the denial of the right to be educated.

The process of democratic development in Albania was associated with major political, institutional, economic and psychological crisis. In this context, appeared a new form of discrimination because of the position of the parents. It reappeared in the series for the killings because of the feud and revenge and consequently, inter alia attitude of many children in "house arrest" and dropping out of school. The situation is especially difficult in the northern districts of the country. The causes of this phenomenon are the historical, political, cultural, social, and psychological development of the population. Albanian legislation does not provide any specific provision regarding non-discrimination of children because of the status, activities, expressed opinions, or beliefs in his parents, etc.

\footnotetext{
${ }^{3}$ Family Code of Republic of Albania, Article 102/103

${ }^{4}$ Code of Civil Procedure of Republic of Albania, Article 351
} 


\subsection{Trafficking of Minors}

A negative phenomenon associated with minors, is their illegal trafficking. According to partial data, the Committee on Equal Opportunities, about 4,000 childrens have emigrated unaccompanied by parents (3000 in Greece and 1000 in Italy). This category of children happened in other countries, far from her family and care, often located many risks facing maltreatment, physical and sexual abuse, involvement in worst forms of labor, trafficking and other illegal activities. In some cases children are sold by their parents, or used by the criminal mafia networks for profit. According to these sources of recruitment of child trafficking are:

- From divorced families and with lack of family care

- From families with many children and in an awkward economic situation

- By rural families who hope in aid of children

- Orphaned and careless Children

- From families whose parents have left for employment abroad

Children who have dropped out of school have been taken with begging and other illegal activities.The living conditions of trafficked minors in most cases are miserable, hard work and overtime and minimum wage just to feed. These children are preferred for traffickers, because they cost less and benefit from their work is growing. Child trafficking routes are usually similar to those of human trafficking, but traffickers also used fake documents as their parents or guardians.

Albanian legislation provides specific crime as "human trafficking" expressed in human trafficking, prostitution, women trafficking, the trafficking of children. Albanian Criminal Code provides sanctions for offenses related directly or indirectly to human trafficking. These include offenses mentioned above, as well as kidnapping and child less than 14 years old, unlawful deprivation of liberty by endangering life or suffering associated with severe physical beatings, sexual.

Albania has undertaken a number of initiatives and has collaborated with other countries, especially neighboring ones, and this phenomenon is more evident in the fight against these phenomena through bilateral or multilateral agreements or by adhering to the existing ones. It is raised a antitraffick center which in collaboration with countries like Italy, Germany, and Greece fights human trafficking particularly of women and children.

\section{Legal Framework}

\subsection{Criminal Code}

Absent domestic violence circumstance (specific) in certain offenses, such as rape, beatings and other acts of violence, killing, wounding, etc. There are no provisions for the protection of children from violence, abuse, neglect and family members.Lacks some provisions prohibiting / punishing children in such situations where they may become witnesses of violence (which, though indirectly, largely affects those in their normal development, and physical and psychological wellbeing). The policies of sentence are not enough severe to domestic violence. Also, it doesnt provided some alternative sentences that are more appropriate for cases of domestic violence. No specific predictions for the protection of elderly family members from violence abuse and neglect.

\subsection{Code of Criminal Procedure}

Prosecution of some offenses, the Criminal Procedure Code relates only with initiative of the victim, creating the impression and the wrong message that domestic violence is not as important as the State to (mostly), but it is a matter between private parties.

Also the Criminal Procedure Code, does not follow the policy of not dismissing the case, the complainant withdraws from the process. Given that in cases of domestic violence victims often than not withdraw the report from fear and pressure, Criminal Procedure Code should provide for provisions that allow the prosecutor to continue the criminal prosecution even if the victim withdraws cases of domestic violence.

\subsection{The family Code}

1. Article 62 of the Family Code provides for the eviction of spouse abusers, only implying violence between 
spouses and not violence against other members of the family (child) ${ }^{5}$.

2. So far, this provision has not been accompanied by the necessary procedural provisions that regulate how this measure will be taken, its duration, etc., but these shortcomings are addressed by the new law on domestic violence.

3. Lacks specific procedures, and more simplified, for dissolution of marriage on grounds of violence.

4. Also, there is no special arrangement for the consequences that may bring domestic violence to the exercise of parental responsibility, leaving one parent to child growth and education, the right to visit or residence, etc..

The Albanian existing legislation there is no binding provision designed specifically for reporting any act of violence against children. Albanian legislation does not envisage specific procedures for appeal the forms of violence occurring in the family or at home, in public and private schools, other state institutions and private child care, children's residential centers, in health institutions, etc..

With the exception of setting procedures regarding specific cases where juveniles commit crimes, the Albanian legislation provided no special procedural rules regarding violence against children

\section{Conclusions}

In general, the laws of the various forms of violence against children have a general nature, in the sense that there are certain specified contexts. Thus, with the exception of a single Article in the Normative Provisions of Pre-University Education System, which speaks specifically prohibiting the exercise of physical and psychological violence against children in school, in the Albanian legislation, there is no specific provision for various aspects of violence against children conducted in homes, schools, other institutions and mental health care, children's residential centers, detention institutions, community, public areas, etc.. However, the legal framework for domestic violence is still incomplete:

Although there are several structures and sectoral policies, does not exist a comprehensive policy of harmonizing cross-cutting, equipped with complete legislation, structural mechanisms, financial resources and human resources, which has the ability to monitor and improve the situation of violence against children.

Compilation of existing policies and programs that address violence against children in Albania at the highest levels of institutional decision was made without consulting directly with children. Meanwhile, the trend to include children in the planning, implementation and monitoring of activities at nonprofit organizations are constantly occupies more space.

Actually there are no mechanisms for monitoring existing policies and programs (public or private, non-profit organizations) regarding violence against children.

\section{References}

The Civil Code of Republic of Albania

The Family Code of Republic of Albania

The Criminal Code of Republic of Albania

Costitution of Republic of Albania

${ }^{5}$ Article 62 of the Family Code of Republic of Albania 
